\title{
EVALUASI SISTEM MANAJEMEN USAHA PEMBIBITAN SAPI BALI TERINTEGRASI DENGAN PERKEBUNAN KELAPA SAWIT DI KABUPATEN PASAMAN BARAT, PROVINSI SUMATERA BARAT
}

\section{Evaluation of Business Management Systems of Bali Cattle Breeding Integrated with The Palm Oil Plantation in Pasaman Barat District, West Sumatera Province}

\author{
Bagus Dimas Setiawan, Arfa'i, Yuliaty Shafan Nur
}

Faculty of Animal Husbandry, Andalas University, Padang City

Jln.Limau Manis, Campus Unand, Padang- 25163, West Sumatera, Padang City, Indonesia

Email: bagusdimassetiawan@gmail.com

\begin{abstract}
The research objective was to evaluate: 1) Implementation of integration of Bali cattle and oil palm plantations; 2) Obstacles faced in implementing the integration of Bali cattle with oil palm plantations. The study was conducted in Pasaman Barat District, which received assistance of fund from Directorate General of Animal Husbandry in 2012 in the project of integration of beef cattle with oil palm plantation. The method used were survey method, direct observation and using questionnaire. Respondents involved were members of farmer-group who carried out the integration of Bali cattle and palm oil plantation program as many as 56 people from four groups. Data was analyzed using descriptive analysis and comparing the results obtained with the objectives of the integration program itself. The results showed that the effort to integrate Bali cattle with oil palm plantation business was not optimal. The feedstuff given to cattle were superior grass and field grass originating from oil palm plantations. However, oil palm fronds and leaves have not been utilized, and palm oil industry waste in the form of palm mud, fiber palm oil, and palm kernel meal have not been used optimally as well. Utilization of cattle feces as fertilizer for oil palm plants has been used in several groups, but still in the form of untreated fertilizers. The obstacles faced in implementing this integration system are such as the lack of knowledge of farmers about integration, and the mastery of livestock waste processing technology and waste from oil palm plantations is still low, so that the application of integration has not been optimally carried out.
\end{abstract}

Keywords: Bali Cattle, Integration, Oil Palm Plantation, Pasaman Barat District, Survey Method.

\section{PENDAHULUAN}

Produktivitas ternak sapi yang masih rendah memaksa pemerintah untuk melakukan impor sapi bakalan dari luar negeri, sehingga Indonesia di khawatirkan menjadi salah satu negara yang menjadi net-importir untuk sapi bakalan terbesar di dunia (Diwyanto, 2008), jika hal ini terjadi dan tanpa adanya upaya yang serius dari pemerintahan pusat saat ini, maka di khawatirkan pada tahun selanjutnya Indonesia akan terus menerus impor bakalan ternak sapi potong untuk dapat memenuhi kebutuhan daging yang ada di Indonesia, dimana jumlah pasokan impor pada sapi bakalan sebanyak 800.000 ekor dan dalam bentuk daging beku setara dengan 781.117 ekor dan populasi sapi potong nasional pada tahun 2015 dan 2016 sekitar 15,4 juta ekor dan 16,1 juta ekor dengan jumlah pertumbuhan populasi ternak sapi potong yang ada di Indonesia saat ini hanya sekitar 4,36\% dari jumlah populasi ternak sapi yang ada (Direktorat Jenderal Peternakan dan Kesehatan Hewan, 2017).

Sistem pemeliharaan usaha pembibitan pada sapi potong yang ada di Provinsi Sumatera Barat pada umumnya masih dilakukan secara konvensional. Pakan hijauan yang berasal dari rumput alam yang didapatkan pada lahan penggembalaan, merupakan andalan peternak sapi sebagai sumber pakan hijauan bagi ternak dengan sedikit penambanhan jenis pakan ternak yakni berupa konsentrat sapi, sehingga tingkat produktivitas ternak sapi potong ini menjadi rendah. Ketersediaan pakan yang bermutu bagi ternak merupakan salah satu kendala dalam 
peningkatan produksi ternak sapi potong di Provinsi Sumatera Barat.

Perkebunan kelapa sawit berpotensi untuk bisa diintegrasikan dengan usaha peternakan sapi Bali. Umar (2009) menyatakan bahwa sapi lokal mampu mengkonsumsi pakan yang berserat tinggi seperti hijauan segar dan konsentrat dalam jumlah cukup banyak, bahan pakan tersebut dapat disediakan oleh industri atau perkebunan kelapa sawit, selanjutnya produk hasil ikutan perkebunan kelapa sawit dapat dimanfaatkan sebagai pakan ternak ruminansia. Sistem usaha integrasi sapi Bali dengan perkebunan kelapa sawit dilakukan dengan menggunakan konsep LEISA yaitu (Low Ekternal Input Suistinable Agriculture) yang merupakan simbiosis mutualisme antara tanaman perkebunan dan ternak, sehingga dapat memberi keuntungan pada kedua subsektor tersebut.

Program keterpaduan antara perkebunan kelapa sawit dan sapi Bali harus didukung dengan penerapan teknologi yang tepat dan sesuai sehingga produksi yang dihasilkan dapat lebih efisien, berdaya saing dan berkelanjutan. Direktorat Jenderal Bina Produksi Peternakan Departemen Pertanian pada tahun 2012 meluncurkan bantuan yang bersumber dari dana APBN dalam bentuk program yang disebut dengan Sistem Integrasi Sapi dan Kelapa Sawit (SISKA) ke beberapa kabupaten di Sumatera Barat termasuk Kabupaten Pasaman Barat yang merupakan daerah sentra pembibitan usaha sapi potong dengan luas perkebunan kelapa sawit yang sudah mencapai $102.200 \mathrm{Ha}$ dan dengan potensi jumlah populasi sapi potong hampir mencapai 19.277 ekor/tahun (BPS Pasaman Barat, 2018).

Upaya yang serius untuk pengembangan usaha pembibitan sapi Bali terintegrasi dengan perkebunan kepala sawit perlu diusahakan agar dapat mengatasi permasalahan/kendala yang dihadapai, maka penelitian ini bertujuan untuk mengevaluasi pelaksanaan sistem integrasi sapi Bali dan perkebunan kelapa sawit dan juga melihat kendala-kendala yang dihadapi dalam pelaksanaan sistem integrasi sapi Bali dengan perkebunan kelapa sawit ini.

\section{MATERI DAN METODE}

\section{Lokasi dan Waktu Penelitian}

Penelitian ini dilakukan di Kabupaten Pasaman Barat, Provinsi Sumatera Barat dengan penetapan lokasi dilakukan secara sengaja (purposive) dengan pertimbangan bahwa Kabupaten Pasaman Barat adalah salah satu daerah sentra/basis pengembangan sapi potong yang sudah ditetapkan langsung oleh Menteri Pertanian Republik Indonesia Nomor
43/Kpts/PD.010/1/2015 tentang Penetapan Komoditas Peternakan di Kabupaten Pasaman Barat, selain itu terdapat kelompok ternak yang telah melakukan sistem usaha integrasi sapi potong dengan perkebunan kelapa sawit di Pasaman Barat.

\section{Metode Penelitian}

Metode yang digunakan pada penelitian ini adalah dengan menggunakan metode survei, yaitu melakukan observasi dan wawancara secara langsung kepada peternak dilokasi area penelitian (Simamora, 2008), selanjutnya untuk memperkuat data pada penelitian ini digunakan juga data sekunder, yang diperoleh dari instansi terkait seperti Badan Pusat Statistik Kabupaten Pasaman Barat, Dinas Peternakan Kabupaten Pasaman Barat, dan Badan Perencanaan dan Pembangunan Daerah Kabupaten Pasaman Barat.

\section{Penentuan responden}

Responden penelitian ditetapkan dengan metode sensus, yaitu semua anggota kelompok yang mendapatkan program bantuan Sistem Integrasi Sapi dengan Perkebunan Kelapa Sawit (SISKA) sebanyak 56 orang. Responden ini berasal dari dua Kecamatan yakni Kecamatan Kinali dan Luhak Nan Duo yang mendapat bantuan integrasi sapi-sawit pada tahun 2012 dan 2014.

\section{Peubah Yang diamati}

Peubah yang diamati dalam penelitian ini terdiri dari beberapa aspek dan fokus dengan melihat keadaan saat ini sebagai berikut: 1) Karakteristik peternak, 2) Manajemen pemeliharaan sistem integrasi, 3) Usaha perkebunan kelapa sawit, 4) Pemanfaatan limbah, dan 5) Kendala serta solusi dalam pengembangan SISKA.

\section{Analisis Data}

Data yang diperoleh dianalisis secara deskriptif dan disajikan dalam tabel, kemudian dibandingkan dengan literatur serta petunjuk teknis pelaksanaan integrasi ternak dan tanaman untuk dapat mengetahui permasalahan yang dihadapi oleh peternak dilihat dari alasan mereka terkait dengan pencapaian sasaran program dan pengetahuan mereka terhadap penggunaan teknologi pendukung sistem integrasi

\section{HASIL DAN PEMBAHASAN}

\section{Gambaran Umum Wilayah}

Kabupaten Pasaman Barat adalah salah satu Kabupaten yang ada di Sumatera Barat yang 
secara demografis daerah ini dilalui oleh garis Khatulistiwa yang terletak antara $0^{\circ} 03^{\prime}$ lintang utara - $0^{\circ} 11^{\prime}$ lintang selatan dan antara 99 $10^{\prime}$ $100^{\circ} 04^{\prime}$ bujur timur. Luas wilayah Kabupaten Pasaman adalah sekitar 3.887,77 $\mathrm{km}^{2}$ atau 9,92\% dari luas wilayah Provinsi Sumatera Barat yang ada saat ini. Jumlah penduduk di Kabupaten Pasaman Barat, menurut hasil dari Proyeksi Penduduk Tahun 2017, berjumlah sebanyak 427,295 jiwa dengan komposisi 216,093 jiwa laki-laki dan 211,202 jiwa perempuan dengan rasio jenis kelamin 102 jiwa untuk laki-laki setiap 100 jiwa perempuan. Kabupaten Pasaman Barat adalah salah satu dari sembilan kabupaten di Sumatera Barat yang berpotensi dalam pengembangan perkebunan kelapa sawit dengan luas area perkebunan kelapa sawit mencapai 102,200 Ha dengan populasi ternak ruminasisa sebesar 19,277 ekor pada tahun 2017 (BPS Pasaman Barat, 2018). Pada tahun 2012 Pemerintah pusat, dalam hal ini Direktorat Jenderal Bina Produksi Peternakan Departemen
Pertanian telah meluncurkan bantuan yang bersumber dari dana APBN dalam bentuk program yang disebut dengan Sistem Integrasi Sapi dan Kelapa Sawit (SISKA) ke beberapa kabupaten daerah sentra yang ada di Propinsi Sumatera Barat, termasuk di Kabupaten Pasaman Barat.

\section{Karakteristik Peternak}

Hasil data dari Dinas Peternakan Kabupaten Pasaman Barat adalah kelompok ternak yang telah melaksanakan program SISKA tahun anggaran 2012, yaitu Kelompok Tani Lubuk Gadang (Kecamatan Luhak Nan Duo) dan Tanjung Keramat (Kecamatan Kinali), serta pada anggaran program tahun 2014, yaitu Kelompok Tani Makmur (Kecamatan Luhak Nan Duo) dan Kelompok Jadi Makmur (Kecamatan Kinali). Profil dan karakteristik peternak anggota kelompok tani-ternak penerima bantuan program SISKA dapat dilihat pada Tabel 1.

Tabel 1. Karakteristik Peternak (Breeder characteristics)

\begin{tabular}{|c|c|c|c|c|c|c|c|c|c|c|}
\hline \multirow{3}{*}{$\begin{array}{c}\text { Uraian } \\
\text { (Description) }\end{array}$} & \multicolumn{8}{|c|}{$\begin{array}{c}\text { Kelompok Pengembangan Integrasi Sapi-Sawit } \\
\text { (Development of Integration Cattle-Palm Oil Groups) }\end{array}$} & \multirow{3}{*}{$\sum$} & \multirow{3}{*}{$(\%)$} \\
\hline & \multicolumn{2}{|c|}{ LG } & \multicolumn{2}{|c|}{ TK } & \multicolumn{2}{|c|}{ TM } & \multicolumn{2}{|c|}{$\mathbf{J M}$} & & \\
\hline & Freq & $\%$ & Freq & $\%$ & Freq & $\%$ & Freq & $\%$ & & \\
\hline \multicolumn{11}{|l|}{ Umur peternak sapi } \\
\hline$<25$ tahun & 0 & 0,0 & 1 & 11,1 & 0 & 0,0 & 1 & 5,9 & 2 & 3,57 \\
\hline 25-64 tahun & 16 & 100,0 & 8 & 88,9 & 14 & 100,0 & 16 & 94,1 & 54 & 96,43 \\
\hline$>64$ tahun & 0 & 0,0 & 0 & 0,0 & 0 & 0,0 & 0 & 0,0 & 0 & 0,00 \\
\hline Total & 16 & 100,0 & 9 & 100,0 & 14 & 100,0 & 17 & 100,0 & 56 & 100,00 \\
\hline \multicolumn{11}{|l|}{ Pendidikan terakhir } \\
\hline Tidak tamat & 3 & 18,8 & 0 & 0,0 & 0 & 0,0 & 0 & 0,0 & 3 & 5,36 \\
\hline SD & 9 & 56,3 & 3 & 33,3 & 5 & 35,7 & 14 & 82,4 & 31 & 55,36 \\
\hline SMP & 2 & 12,5 & 4 & 44,4 & 2 & 14,3 & 1 & 5,9 & 9 & 16,07 \\
\hline SMA/SMK & 2 & 12,5 & 2 & 22,2 & 6 & 42,9 & 2 & 11,8 & 12 & 21,43 \\
\hline $\mathrm{Pt}$ & 0 & 0,0 & 0 & 0,0 & 1 & 7,1 & 0 & 0,0 & 1 & 1,79 \\
\hline Total & 16 & 100,0 & 9 & 100,0 & 14 & 100,0 & 17 & 100,0 & 56 & 100,00 \\
\hline \multicolumn{11}{|l|}{ Pengalaman beternak } \\
\hline 3-11 tahun & 13 & 81,3 & 6 & 66,7 & 7 & 50,0 & 14 & 82,4 & 40 & 71,43 \\
\hline 12-20 tahun & 2 & 12,5 & 1 & 11,1 & 1 & 7,1 & 2 & 11,8 & 6 & 10,71 \\
\hline$>20$ tahun & 1 & 6,3 & 2 & 22,2 & 6 & 42,9 & 1 & 5,9 & 10 & 17,86 \\
\hline Total & 16 & 100,0 & 9 & 100,0 & 14 & 100,0 & 17 & 100,0 & 56 & 100,00 \\
\hline \multicolumn{11}{|c|}{ Pekerjaan utama responden } \\
\hline Petani & 16 & 100,0 & 9 & 100,0 & 13 & 92,9 & 17 & 100,0 & 55 & 98,21 \\
\hline PNS & 0 & 0,0 & 0 & 0,0 & 0 & 0,0 & 0 & 0,0 & 0 & 0,00 \\
\hline Wiraswasta & 0 & 0,0 & 0 & 0,0 & 1 & 7,1 & 0 & 0,0 & 1 & 1,79 \\
\hline Total & 16 & 100,0 & 9 & 100,0 & 14 & 100,0 & 17 & 100,0 & 56 & 100,00 \\
\hline
\end{tabular}

Sumber : Hasil Penelitian, 2019.

Keterangan: LG (Lubuk Gadang), TK (Tanjung Keramat), TM (Tani Makmur), JM (Jadi Makmur), SD (Sekolah Dasar), SMP (Sekolah Menengah Pertama), SMA (Sekolah Menengah Atas), SMK (Sekolah Menengah Kejuruan), PNS (Pegawai Negeri Sipil) 
Kemampuan dan kondisi fisik pada manusia akan optimal jika berada pada skala umur yang masih produktif. Hasil penelitian ini menunjukan bahwa umur responden $(96,43 \%)$ berada pada usia yang masih produktif (25-64 tahun). Hasil ini sesuai dengan pendapat Badan Pusat Statistik (2010) yang mengelompokkan usia penduduk menjadi 3 kelompok, diantaranya adalah: usia belum produktif ( $0-14$ tahun $)$, usia produktif (15-65 tahun) dan usia tidak produktif (66 tahun keatas). Tingginya jumlah peternak yang berada pada usia produktif akan memberikan pengaruh pada produktivitas kerja. Hal ini sesuai dengan yang dikemukakan oleh Pasaribu (2007) bahwa usia akan sangat mempengaruhi produktivitas kerja mengalami penurunan dengan semakin bertambahnya usia seseorang.

Tingkat pendidikan formal ikut mempengaruhi peternak dalam mengelola jenis usahanya, semakin tinggi pendidikan maka wawasannya akan semakin meningkat dan semakin mudah dalam menerima inovasi serta teknologi yang berkembang. Sebagian besar tingkat pendidikan responden adalah sekolah dasar (SD), yaitu sebanyak $55,46 \%$ pada setiap kelompok tani yang mendapat program bantuan integrasi. Hal ini mengindikasikan masih rendahnya kualitas sumber daya manusia (SDM). Rendahnya pengetahuan peternak dalam mengadopsi teknologi merupakan ukuran respon petani terhadap perubahan teknologi. Soekartawi (2002) menyatakan bahwa semakin tinggi tingkat pendidikan seseorang akan semakin baik dan cepat mereka dalam menerima inovasi baru yang diberikan. Kualitas SDM bisa mempengaruhi kelancaran usaha tersebut karena bertindak sebagai penggerak, pengawas dan pelaksana teknis usaha dalam memanfaatkan dan mengelola hasil sumber daya secara optimal dapat memberikan keuntungan sesuai dengan yang diharapkan.

Sebagian besar responden memilih usaha bertani sebagai usaha pokok, yaitu sebesar $98,21 \%$. Responden melakukan usaha bertani untuk dapat memenuhi kebutuhan hidup, sedangkan dalam usaha sapi potong masih berupa usaha sambilan. Peternak dengan umur pengalaman beternak 3-11 tahun sebesar 71,43\%, umur pengalaman 20 tahun sebesar 10,71\% dan pengalaman diatas 20 tahun sebesar 17,86\%. Hasil penelitian ini menggambarkan bahwa peternak sudah terbiasa memelihara jenis sapi potong, sehingga merupakan suatu kekuatan yang sangat menunjang bagi pengembangan usaha jenis sapi potong, khusunya sistem integrasi sapi dan sawit di masa yang akan datang. Menurut Soeharsono et al., (2010) mengemukakan bahwa semakin lama pengalaman seorang peternak membudidayakan sapi, memungkinkan mereka untuk lebih banyak belajar dari pengalamannya , sehingga dapat dengan mudah menerima inovasi serta teknologi yang berkaitan dengan usaha ternak sapi potong, menuju perubahan yang lebih baik.

\section{Manajemen Pemeliharaan}

Hasil penelitian menunjukkan bahwa bibit sapi yang digunakan oleh peternak adalah bantuan dari pemerintah melalui Direktorat Jenderal Peternakan Departemen Pertanian pada tahun 2012 yang bersumber dari Dana APBN dalam bentuk kegiatan Sistem Integrasi Sapi dan Perkebunan Kelapa Sawit (SISKA). Kabupaten Pasaman Barat merupakan salah satu penerima program SISKA dan merupakan sentra pembibitan usaha sapi potong lokal, yakni sapi Bali yang tersebar di beberapa kecamatan yang di Kabupaten Pasaman Barat.

Sapi yang diperoleh kelompok peternak adalah sapi Bali berumur 18-24 bulan. Pada umur tersebut, ternak sapi sudah mengalami dewasa kelamin dan tubuh, sehingga bisa dilakukan perkawinan. Menurut AAK (2011), bangsabangsa sapi tropis mengalami dewasa kelamin pada usia 1,5-2 tahun dan mencapai dewasa tubuh pada umur 2-2,5 tahun, maka sapi dapat dikawinkan secara tepat. Upaya untuk dapat menghasilkan bibit ternak yang baik bisa dilakukan dengan cara seleksi. Seleksi dilakukan untuk dapat memilih sapi yang dianggap mempunyai mutu genetik yang baik untuk bisa dikembangkan lebih lanjut serta memilih ternak yang kurang baik untuk dapat dipisahkan dari bibit yang berkualitas baik. Penyeleksian dapat dilakukan dengan melihat genetik dan sifat-sifat ternak tersebut (Hafez dan Hafez, 2013).

Secara umum kriteria dari seleksi bibit bakalan ternak yang baik menurut Direktorat Pembibitan Ternak (2012) adalah sebagai berikut: 1) kesesuaian warna tubuh dengan bangsa, baik pada sapi lokal maupun pada sapi dari luar; 2) melihat dan memeriksa recording-nya untuk dapat mengetahui riwayat hidupnya sejak lahir (tanggal lahir, genetik induknya, berat lahir dan perkembanganya, serta penyakit yang pernah dialaminya); 3) sehat (selalu aktif, reaktif dan peka, nafsu makan tinggi, tidak ada luka, mata jernih, bulu halus dan bersih mengkilap, tidak kusam, bokong bersih serta padat); 4) bentuk badan panjang, kaki pendek, kuat, dada lebar dan dalam; 5) standar pemilihan (seleksi) bibit berdasarkan tinggi badan untuk masing-masing bangsa berbeda diantaranya pemilihan tergantung kepada bibit nasional, pemilihan tergantung 
kepada standar populasi yang ada; 6) umur antara 1-2 tahun (sapi muda) dan 2-3 tahun (sapi dewasa); 7) bentuk kerangka yang besar dan panjang (kepala dan moncong besar, tulang punggung lurus serta bulu halus); dan 8) untuk calon indukan sudah menunjukan birahi pertama pada umur $\leq 18$ bulan, service per conception $(\mathrm{S} / \mathrm{C}) \leq 2$, dan $\mathrm{CI} \leq 14$ bulan. Kriteria bibit kelompok tani dalam manajemen pemeliharaan disajikan pada Tabel 2.

\section{Sistem Pemberian Pakan}

Pakan yang tersedia di area padang pengembalaan, serta jenis pakan konsentrat yang diberikan oleh responden terhadap sapi, berupa dedak dan limbah perkebunan kelapa sawit. Hijauan yang diberikan pada ternak berupa hijauan unggul seperti rumput gajah (Pennisetum purpureum) dan rumput lapangan, dengan komposisi $65 \%$ rumput unggul dan 35\% rumput lapangan. Sistem pemberian pakan ternak pada setiap kelompok tani berbeda-beda, akan tetapi untuk kebutuhan pakan jenis rumput hijauan pada sapi adalah dengan rata-rata pemberian hijauan 20 $\mathrm{kg} /$ ekor. Jenis dan sistem pemberian pakan oleh kelompok peternak di wilayah sentra pengembangan sapi disajikan pada Tabel 3.

Penggunaan limbah hasil dari perkebunan kelapa sawit sebagai pakan ternak secara umum belum dimanfaatkan dengan baik oleh beberapa kelompok ternak tersebut, hal ini disebabkan karena pakan hijauan masih banyak tersedia, dan pengetahuan peternak masih rendah terhadap pengolahan limbah sawit sebagai pakan ternak. Hanya satu kelompok yang menerapkan sistem integrasi berupa limbah dari kebun sawit, yaitu kelompok tani Tanjung Keramat yang memberikan pakan berupa hijauan dan penambahan konsentrat serta fermentasi limbah pelepah sawit seperti solid. Pakan fermentasi ini diberikan pada saat ketersediaan sumber hijauan tidak bisa terpenuhi. Pemberian pakan fermentasi pelepah sawit sebanyak $5 \mathrm{~kg} / \mathrm{ekor} /$ hari. Pakan fermentasi ini disimpan dalam drum kedap udara dan dapat disimpan selama 3 bulan.

Tabel 2. Manajemen Pemeliharaan (Maintenance management)

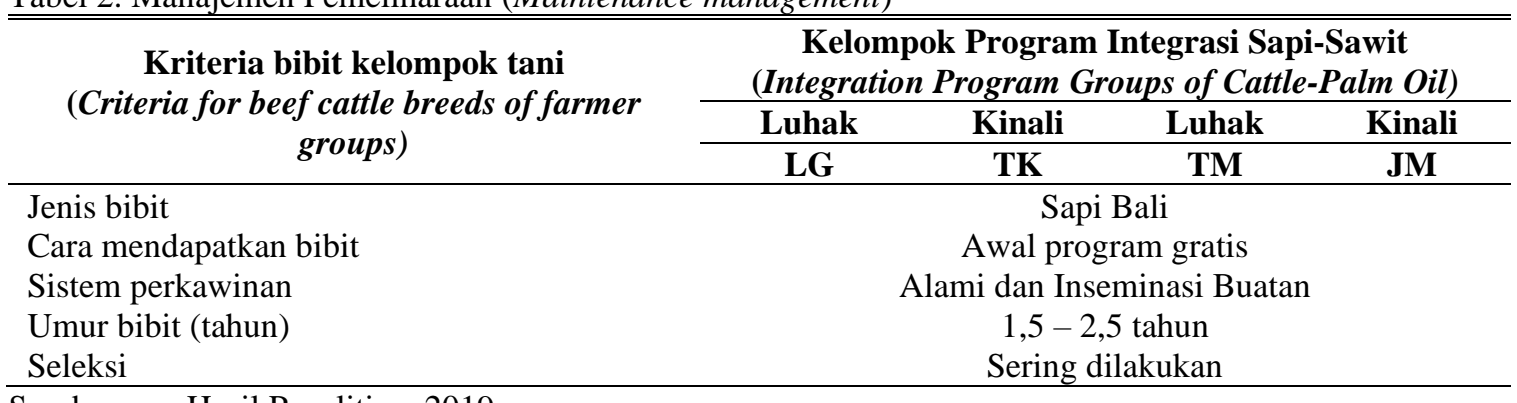

Sumber : Hasil Penelitian, 2019.

Keterangan: LG (Lubuk Gadang), TK (Tanjung Keramat), TM (Tani Makmur), dan JM (Jadi Makmur)

Tabel 3. Sistem pemberian pakan (Feeding system)

\begin{tabular}{|c|c|c|c|c|c|c|}
\hline \multirow[t]{2}{*}{$\begin{array}{l}\text { Sistem pemberian pakan } \\
\quad(\text { Feeding system) }\end{array}$} & \multicolumn{4}{|c|}{$\begin{array}{c}\text { Pengembangan Integrasi Sapi-Sawit } \\
\text { (Development of Integration Cattle-Palm } \\
\text { Oil Groups) }\end{array}$} & \multirow[t]{2}{*}{$\sum$} & \multirow[t]{2}{*}{$(\%)$} \\
\hline & LG & TK & TM & JM & & \\
\hline Hijauan & - & - & - & - & - & - \\
\hline Rumput unggul & - & - & - & - & - & - \\
\hline $\begin{array}{l}\text { Rumput lapangan + unggul } \\
\text { Konsentrat }\end{array}$ & 16 & 9 & 14 & 17 & 56 & 100 \\
\hline Diberikan & - & 9 & - & - & 9 & 16,1 \\
\hline $\begin{array}{l}\text { Tidak diberikan } \\
\text { Waktu pemberian }\end{array}$ & 16 & - & 14 & 17 & 47 & 83,9 \\
\hline Pagi & 16 & & 14 & 17 & 47 & 83,9 \\
\hline Sore & - & - & - & - & - & - \\
\hline Pagi + sore & - & 9 & - & - & 9 & 16,1 \\
\hline
\end{tabular}

Sumber : Hasil Penelitian, 2019.

Keterangan: LG (Lubuk Gadang), TK (Tanjung Keramat), TM (Tani Makmur), JM (Jadi Makmur) 
Tatalaksana Pemeliharaan Ternak

Hasil penelitian menunjukan bahwa sistem pemeliharaan terbagi atas dua sistem, yaitu sistem pemeliharaan secara intensif dan secara semi intensif, yang terlihat pada Tabel 4. Sistem intensif dilakukan di tiga kelompok tani, yakni: Kelompok Lubuk Gadang, Tani Makmur dan Jadi Makmur. Kelebihan dari pola pemeliharaan intensif antara lain lebih mudah dalam pengontrolan, manajemen pengumpulan feses, manajemen reproduksi, serta pengumpulan pelepah dan daun sawit, sedangkan kelemahannya adalah sapi tidak diarahkan untuk memakan gulma yang terdapat disekitar lahan perkebunan kelapa sawit, serta peternak harus menyediakan waktu untuk mengarit rumput.

Pada sistem pemeliharaan semi intensif yang dilakukan oleh kelompok tani Tanjung Keramat, ternak dikeluarkan dari kandang pada siang hari dan dimasukkkan ke kandang pada malam hari, serta ketika dikandangkan ternak sapi diberi pakan hijauan dan pakan olahan. Selain itu, ternak ini diarahkan untuk memakan gulmagulma yang terdapat disekitar area lahan perkebunan kelapa sawit sehingga bisa menghemat biaya penyiangan.

Direktorat Pakan Ternak (2011) menyatakan bahwa pada sistem dan pola pemeliharaan dengan pengembalaan ternak di kawasan perkebunan kelapa sawit, dengan umur tanaman utama dibawah lima tahun, lebih disukai peternak dan dapat menghemat biaya penyiangan sebesar 32\%-73\%, sedangkan pola pemeliharaan intensif dapat mengontrol keadaan ternak itu sendiri dan pakan yang diberikan.

Dirjen Bina Produksi Peternakan (2012) menyatakan pola pemeliharaan sapi dengan intensif lebih baik dibandingkan dengan semi intensif, sistem dengan pola intensif dapat memelihara sapi lebih banyak, yaitu sekitar 2 ekor sapi dewasa/Ha/tahun, karena memudahkan pemilik dalam tata laksana pemeliharaan serta kotoran sapi juga akan lebih mudah untuk dikumpulkan serta diolah lebih lanjut.

Hasil penelitian menunjukan bahwa kandang sapi Bali dibuat sesederhana mungkin dengan memanfaatkan bahan lokal yang ada. Sebagian besar bangunan kandang ternak terbuat dari kayu, atap seng, lantai kandang dari semen, dinding kayu dan bambu. Kandang sapi umumnya dibersihkan setiap hari. Perlengkapan yang ada di area kandang terdiri dari tempat pakan, minum, gerobak, drum, pipa air dan penampung kotoran ternak. Rosita (2004) menyatakan bahwa kandang ternak yang baik dilengkapi dengan perlengkapan kandang berupa tempat pakan dan tempat penampungan feses dan urine, serta memiliki kandang khusus yang baik dan memadai sebagai tempat indukan sapi yang akan melahirkan.

Tabel 4. Tatalaksana pemeliharaan (Maintenance procedures)

\begin{tabular}{|c|c|c|c|c|c|c|c|}
\hline \multirow[t]{2}{*}{ No } & \multirow[t]{2}{*}{$\begin{array}{l}\text { Sistem pemeliharaan } \\
\text { (Maintenance system) }\end{array}$} & \multicolumn{4}{|c|}{$\begin{array}{c}\text { Pengembangan Integrasi Sapi-Sawit } \\
\text { (Development of Integration Cattle- } \\
\text { Palm Oil Groups) }\end{array}$} & \multirow[t]{2}{*}{$\sum$} & \multirow[t]{2}{*}{$(\%)$} \\
\hline & & LG & TK & TM & $\mathbf{J M}$ & & \\
\hline \multirow[t]{3}{*}{1} & Sistem pemeliharaan & & & & & & \\
\hline & Intensif & 16 & - & 14 & 17 & 47 & 83,9 \\
\hline & Semi intensif & - & 9 & - & - & 9 & 16,1 \\
\hline \multirow[t]{3}{*}{2} & Bangunan kandang & & & & & & \\
\hline & Semi permanen beton & 16 & 9 & 14 & 17 & 56 & 100 \\
\hline & Semi permanen tanah & - & - & - & - & - & - \\
\hline \multirow[t]{3}{*}{3} & Membersihkan kandang & & & & & & \\
\hline & Setiap hari & 16 & 9 & 14 & 17 & 56 & 100 \\
\hline & Sekali seminggu & - & - & - & - & - & - \\
\hline
\end{tabular}

Sumber : Hasil Penelitian, 2019.

Keterangan: LG (Lubuk Gadang), TK (Tanjung Keramat), TM (Tani Makmur), dan JM (Jadi Makmur)

\section{Pencegahan dan Pengobatan Penyakit}

Berdasarkan hasil penelitian terhadap pencegahan dan pengobatan penyakit sapi Bali, secara umum dilakukan sanitasi kandang dan lingkungan serta dilakukan vaksinasi oleh masing-masing kelompok tani ternak yang ada. Data jenis penyakit disajikan pada Tabel 5.
Penyakit yang pernah menyerang ternak sapi Bali ini adalah penyakit cacingan sebesar $41,1 \%$, penyakit kembung (bloat) sebesar $21,4 \%$, dan penyakit jembrana sebesar $26,8 \%$ serta berak darah sebesar $10,7 \%$. Ternak yang terserang oleh penyakit dipisahkan dari ternak sapi yang lain. Pengobatan penyakit ternak dilakukan dengan cara menghubungi petugas kecamatan melalui 
handphone dan pengobatan dilakukan oleh petugas. Dinas Pertanian Tanaman Pangan Hortitulkura dan Peternakan, Kabupaten Pasaman Barat, memberikan vaksin secara gratis kepada peternak berupa vaksin Septicemia Epizootica, vaksin pencegahan jembrana, vaksin butok dan cacingan. Pengobatan penyakit cacing oleh petugas peternakan dilakukan 6 bulan sekali, sekaligus pemberian vitamin B kompleks bagi ternak untuk menjaga stamina dan kesehatan ternak peliharaan tersebut. Obat ternak yang digunakan harus mengikuti Peraturan Menteri Pertanian No.46/Permentan/PK.210/8/2015, yaitu harus sesuai dengan peruntukan dan memilki nomor pendaftaran (Permentan, 2015).

\section{Luas Tanaman Kelapa Sawit}

Hasil penelitian menunjukkan bahwa luas kebun kelapa sawit yang dimiliki responden bervariasi antara 0,5-1,0 Ha. Luas lahan yang ditanami kelapa sawit masih sekitar 55,4\%. Hal ini berarti bahwa responden peternak masih memiliki kesempatan dan kemampuan untuk meningkatkan skala usaha kepemilikan ternak sapi yang dipelihara di kebun kelapa sawit. Mathius et al. (2007) menyatakan bahwa semakin luas lahan yang dimiliki, maka semakin meningkat produk samping kebun kelapa sawit yang dapat dimanfaatkan sebagai pakan sapi, karena dalam 1 Ha lahan sawit akan mampu menampung 3-5 ekor sapi dewasa. Menurut Direktorat Pakan Ternak (2011) jumlah pelepah dan daun yang dapat diperoleh untuk setiap hektar kebun kelapa sawit mencapai lebih dari 2,3 ton bahan kering. Jumlah tersebut diperoleh dengan asumsi tiap pohon kelapa sawit dapat menghasilkan 22 pelepah dan daun segar/tahun. Adapun untuk pemanfaatan gulma (rumput yang tumbuh di sekitar pohon kelapa sawit), menurut Aritonang (1986), rumput yang tumbuh di sekitar tanaman kelapa sawit yang dihasilkan untuk setiap hektar lahan kelapa sawit adalah 3-5 ton/tahun. Sedangkan untuk jenis leguminosa mencapai 5-7 ton bahan kering/tahun, pada dua tahun pertama penanaman, setelah itu produksi menurun 1-5 ton/tahun pada umur 2 sampai 5 tahun. Data luas tanaman sawit disajikan pada Tabel 6.

Tabel 5. Jenis penyakit (The type of disease)

\begin{tabular}{llccc}
\hline \hline No & & $\begin{array}{c}\text { Jenis Penyakit } \\
\text { (Type of Disease) }\end{array}$ & $\begin{array}{c}\text { Responden } \\
\text { (Respondent) }\end{array}$ & $(\%)$ \\
\hline 1 & Cacingan & 23 & 41,1 \\
2 & Kembung & 12 & 21,4 \\
3 & Jembrana & 15 & 26,8 \\
4 & Berak darah & 6 & 10,7 \\
\hline & Total & 56 & 100,0 \\
\hline
\end{tabular}

Sumber: Hasil Penelitian, 2019.

Tabel 6. Luas tanaman sawit (Palm oil area)

\begin{tabular}{cccc}
\hline \hline Luas lahan $(\mathrm{Ha})$ & $\begin{array}{c}\text { Responden } \\
\text { Land area }(\mathrm{Ha})\end{array}$ & $\mathbf{( \% )}$ \\
\hline $0,5-1$ & 31 & 55,4 \\
& $2-2,5$ & 14 & 25,0 \\
& $>2,5$ & 11 & 19,6 \\
\hline Total & & 56 & 100,0 \\
\hline
\end{tabular}

Sumber: Hasil Penelitian, 2019.

\section{Limbah Hasil Ternak}

Hasil penelitian menunjukkan bahwa untuk pemanfaatan limbah, feses yang berasal dari ternak yang dipelihara diolah menjadi pupuk organik atau kompos, yang kemudian digunakan sebagai pupuk tanaman kelapa sawit. Terdapat tiga kelompok tani-ternak program integrasi yang telah memanfaatkannya, yakni Lubuk Gadang, Tanjung Keramat, dan Jadi Makmur. Pupuk organik yang digunakan berasal dari feses yang diolah secara sederhana, yaitu: feses ditempatkan disuatu tempat penampungan feses disekitar kandang (memiliki atap sederhana), feses disimpan selama lima minggu sambil dibalik tanpa ada perlakuan lain, setelah lima minggu pupuk organik yang sudah jadi langsung digunakan untuk tanaman sawit. Pupuk organik yang telah dihasilkan masih bisa dioptimalkan melalui teknologi pengolahan pupuk, sehingga nilai harganya bisa ditingkatkan dan diharapkan dapat mengurangi penggunaan pupuk an-organik dari luar usaha pertanian. Dengan demikian, biaya 
untuk pembelian pupuk an-organik bisa dikurangi dan efisiensi usaha dapat ditingkatkan. Pemanfaatan limbah ternak dan limbah perkebunan pada kelompok ternak disajikan dalam Tabel 7.

\section{Limbah Perkebunan Kelapa Sawit}

Hasil penelitian ini menunjukkan bahwa teknologi pengolahan limbah dari perkebunan kelapa sawit belum secara optimal dilakukan oleh setiap kelompok, dikarenakan kurangnya tenaga SDM dalam meningkatkan kualitas pakan ternak. Hal ini terjadi karena kurangnya perhatian dari kelompok serta pemerintah daerah setempat yang masih kurang tegas dalam pengembangan usaha pembibitan sapi secara terintegrasi dengan perkebunan kelapa sawit. Selain itu, anggota kelompok masih belum terbiasa menggunakan alat Chopper sehingga alat ini jarang digunakan dalam pembuatan pakan dari limbah pelepah sawit ini, padahal potensi limbah dari perkebunan kelapa sawit ini bisa memberikan asupan pakan pada ternak. Hasil penelitian Doru et al., (2014) didapatkan bahwa dalam 1 (satu) ha kebun sawit menghasilkan pelepah dan daun sawit sebesar 18.083,5 kg BK/tahun, sedangkan produksi pelepah dan daun sawit yang dihasilkan dari lahan milik anggota sebesar $379.753,5 \mathrm{~kg} \mathrm{BK} /$ tahun. Jika pada 1 ekor sapi dewasa berat hidup yakni $250 \mathrm{~kg}$ membutuhkan pakan sebesar 2,3 ton $\mathrm{BK} / \mathrm{th}$, maka potensi pakan yang berasal dari pelepah dan daun sawit adalah sebesar 165,11 UT/tahun.
Alokasi Dana Bantuan Integrasi
Program bantuan integrasi ini merupakan suatu rencana yang melibatkan berbagai unit, yang berisi kebijakan dan serangkaian kegiatan. Kegiatan tersebut diantaranya adalah kegiatan pemanfaatan limbah yang ada, baik dari limbah perkebunan maupun limbah ternak itu sendiri. Limbah perkebunan yang dalam hal ini adalah limbah sawit dapat dimanfaatkan sebagai pakan ternak, dan limbah ternak yang daam hal ini adalah feses, dapat dimanfaatkan sebagai sumber pupuk organik untuk perkembangan tanaman kelapa sawit. Alokasi Dana bantuan bisa dilihat pada Tabel 8.

Tabel 7. Pemanfaatan limbah ternak dan limbah perkebunan (Utilization of livestock and plantation waste)

\begin{tabular}{|c|c|c|c|c|c|c|c|c|}
\hline \multirow{3}{*}{$\begin{array}{l}\text { Uraian } \\
\text { (Description) }\end{array}$} & \multicolumn{8}{|c|}{$\begin{array}{c}\text { Pemanfaatan limbah } \\
\text { (Waste utilization) }\end{array}$} \\
\hline & \multicolumn{2}{|c|}{$\mathbf{L G}$} & \multicolumn{2}{|c|}{ TK } & \multicolumn{2}{|c|}{ TM } & \multicolumn{2}{|c|}{$\mathbf{J M}$} \\
\hline & $\mathbf{Y}$ & $\mathbf{T}$ & $\mathbf{Y}$ & $\mathbf{T}$ & $\mathbf{Y}$ & $\mathbf{T}$ & $\mathbf{Y}$ & $\mathbf{T}$ \\
\hline Limbah ternak & - & - & - & - & - & - & - & - \\
\hline Pupuk kompos & $\mathrm{Y}$ & - & $\mathrm{Y}$ & - & - & - & $\mathrm{Y}$ & - \\
\hline Biogas & - & - & - & - & - & - & - & - \\
\hline Urine untuk pupuk cair & - & - & $\mathrm{Y}$ & - & - & - & - & - \\
\hline Limbah perkebunan & - & - & - & - & - & - & - & - \\
\hline Fermentasi pelepah dan daun sawit & - & - & $\mathrm{Y}$ & - & - & - & - & - \\
\hline Silase & - & - & $\mathrm{Y}$ & - & - & - & - & - \\
\hline
\end{tabular}

Sumber : Hasil Penelitian, 2019.

Keterangan: Y = Iya (Iya dilakukan), T =Tidak (Tidak dilakukan), LG (Lubuk Gadang), TK (Tanjung Keramat), TM (Tani Makmur) dan JM (Jadi Makmur)

Tabel 8. Alokasi dana bantuan program integrasi perkelompok ternak (Allocation of assistance funds for the integration of each group of livestock)

\begin{tabular}{lrrc}
\hline \multicolumn{1}{c}{$\begin{array}{c}\text { Uraian } \\
\text { (Description) }\end{array}$} & $\begin{array}{c}\text { Volume } \\
\text { (volume })\end{array}$ & \multicolumn{1}{c}{$\begin{array}{c}\text { Jumlah } \\
\text { (Total) }\end{array}$} & $(\%)$ \\
\hline Pembelian sapi Bali & Rata-rata 28 ekor & Rp. 210.000.000 & 70 \\
Mesin Chopper & 1 unit & Rp. 45.000 .000 & 15 \\
Pembelian bibit hijauan pakan dan sarana & 1 paket & Rp. 30.000 .000 & 10 \\
produksi pendukung & 1 paket & Rp. 15.000 .000 & 5 \\
Administrasi/Penguatan kelompok & & $* 300.000 .000$ & 100 \\
\hline Jumlah Total & & & \\
\hline
\end{tabular}

Sumber : Hasil Penelitian, 2019.

*Rata-Rata Jumlah Bantuan Integrasi pada setiap kelompok tani 
Hasil penelitian ini juga menjelaskan bahwa pemanfaatan sumber dana bantuan seperti pengadaan sapi Bali masih terbilang kurang, yaitu berkisar $70 \%$, sedangkan berdasarkan petunjuk teknis integrasi sapi dan tanaman, penggunaan dana untuk pengadaan sapi minimal $85 \%$, sisanya digunakan untuk penunjang fasilitas sistem usaha integrasi sapi-sawit. Realisasi pada penggunaan dana yang kurang ini disebabkan karena pengawasan yang kurang dari pemerintah setempat terhadap program yang telah diberikan. Hal ini tentu akan mempengaruhi keberhasilan program yang dilakukan pada setiap anggota kelompok yang telah menjalankan usaha integrasi sapi dan sawit ini. Integrasi sapi dengan kelapa sawit merupakan suatu sistem usaha tani tanamanternak yang potensial dikembangkan di Indonesia karena didukung dengan luas tanam kelapa sawit mencapai 7 juta hektar (Departemen Pertanian, 2010).

\section{Faktor Kendala dan Alternatif Solusi}

Pembangunan usaha peternakan di masa yang akan datang diharapkan mampu mengubah pandangan peternak dari sistem produksi menjadi sistem peternakan dengan konsep agribisnis yang terintegrasi dengan cara optimal. Konsep agribisnis ini merupakan konsep pembangunan pada sektor peternakan yang merupakan suatu sistem yang terdiri dari beberapa sub-sistem yaitu; 1) sub-sistem agribisnis hulu (up-stream agribusiness), kegiatan ekonomi yang menghasilkan sapronak (industri pembibitan, industri pakan); 2) sub-sistem agribisnis usaha peternakan (on-farm agribusiness), kegiatan budidaya ternak; 3) sub-sistem pada sistem agribisnis hilir (down-stream agribusiness), kegiatan ekonomi yang mengolah komoditas peternakan primer menjadi produk olahan (industri pengolahan dan pemasaran ternak); dan 4) sub-sistem jasa penunjang sestem agribisnis (supporting system), kegiatan yang menyediakan jasa bagi dari ketiga sub-sistem agribisnis lainnya (Saragih, 2000).

Sistem usaha integrasi perkebunan dan ternak sapi ini diharapkan dapat menjadi bagian dalam usaha tani yang berkelanjutan dengan konsep integrasi. Sistem integrasi sapi-sawit diharapkan dapat mengurangi permasalahan limbah sapi (kotoran) dan limbah dari kegiatan usaha perkebunan kelapa sawit. Pemanfaatan lahan didasarkan pada: 1) lahan sebagai sumber pakan ternak; 2) semua jenis lahan cocok sebagai sumber pakan; 3) pemanfaatan lahan untuk peternakan yang diartikan sebagai usaha penyerasian antara peruntukan lahan dengan sistem usaha pertanian. Potensi pengembangan sapi potong ini masih dapat ditingkatkan melalui inovasi teknologi dan implementasi integrasi tanaman perkebunan dan ternak (Crop Livestock System), yakni melalui optimalisasi pemanfaatan limbah usaha tani tanaman untuk pakan dan pemanfaatan kotoran ternak untuk pupuk organik untuk jenis tanaman pertanian (Arfa'i, 2009). Permasalahan dan alternatif solusi disajikan pada Tabel 9.

Tabel 9. Permasalahan dan alternatif solusi (Problems and alternative solutions)

\begin{tabular}{|c|c|c|}
\hline $\begin{array}{l}\text { Faktor } \\
\text { (Factor) }\end{array}$ & $\begin{array}{l}\text { Kendala } \\
\text { (Obtacles) }\end{array}$ & $\begin{array}{c}\text { Alternatif solusi } \\
\text { (Alternative solutions) }\end{array}$ \\
\hline \multirow{5}{*}{$\begin{array}{l}\text { Internal } \\
\text { (Internal) }\end{array}$} & $\begin{array}{l}\text { 1. Beternak usaha } \\
\text { sambilan }\end{array}$ & $\begin{array}{l}\text { Peningkatan Skala usaha yang telah dijalankan, dan fokus pada } \\
\text { sistem usaha integrasi yang sudah dijalankan di kelompok tani. }\end{array}$ \\
\hline & $\begin{array}{l}\text { 2. Adopsi } \\
\text { Teknologi } \\
\text { Rendah }\end{array}$ & $\begin{array}{l}\text { 1. Penguatan sistem informasi dan penyuluhan kepada } \\
\text { peternak terhadap teknologi peternakan. } \\
\text { 2. Diskusi dengan pakar teknologi di bidangnya. }\end{array}$ \\
\hline & $\begin{array}{l}\text { 3. Pemasaran } \\
\text { Ternak }\end{array}$ & $\begin{array}{l}\text { Memperbaiki sistem pemasaran seperti pengadaan RPH (Rumah } \\
\text { Potong Hewan) dan Pasar Ternak terdekat. }\end{array}$ \\
\hline & $\begin{array}{l}\text { 4. Pemasaran } \\
\text { kompos }\end{array}$ & $\begin{array}{l}\text { 1. Bekerjasama dengan kelompok tetangga lain untuk akses } \\
\text { pemasaran yang luas. } \\
\text { 2. Bekerjasama dengan dinas dan institusi setempat. } \\
\text { 3. Membuat kemasan kompos yang bagus, unik dan } \\
\text { menarik. } \\
\text { 4. Kualitas kompos yang perlu diperbaiki (harus dianalisis). }\end{array}$ \\
\hline & $\begin{array}{l}\text { 5. Sumberdaya } \\
\text { manusia (SDM) }\end{array}$ & $\begin{array}{l}\text { 1. Peningkatan bidang pengetahuan dan keterampilan } \\
\text { peternak dengan melakukan diskusi berkala, sosialisasi } \\
\text { dan pelatihan peternak dan khususnya pada bidang } \\
\text { manajemen keuangan dan manajemen koperasi. } \\
\text { 2. Pengetahuan dalam peningkatan usaha pada sektor hilir. }\end{array}$ \\
\hline
\end{tabular}




\begin{tabular}{|c|c|c|}
\hline $\begin{array}{l}\text { Faktor } \\
\text { (Factor) }\end{array}$ & $\begin{array}{l}\text { Kendala } \\
(\text { Obtacles })\end{array}$ & $\begin{array}{c}\text { Alternatif solusi } \\
\text { (Alternative solutions) }\end{array}$ \\
\hline & 6. Jenis Pakan & $\begin{array}{l}\text { Peningkatan jumlah penanaman HMT (Hijauan Makanan Ternak) } \\
\text { unggulan (gajah dan setaria) dan pemberian konsentrat dari limbah } \\
\text { perkebunan yang teratur serta harus rutin membuat fermentasi hasil } \\
\text { limbah sawit. }\end{array}$ \\
\hline \multirow{10}{*}{$\begin{array}{l}\text { Eksternal } \\
\text { (External) }\end{array}$} & $\begin{array}{l}\text { 1. Lahan produksi } \\
\text { kompos }\end{array}$ & $\begin{array}{l}\text { Membuat regulasi untuk lahan pada produksi kompos dan } \\
\text { perluasan lahan perkebunan sawit. }\end{array}$ \\
\hline & $\begin{array}{l}\text { 2. Gangguan } \\
\text { Kesehatan }\end{array}$ & $\begin{array}{l}\text { 1. Peningkatan sarana kesehatan dan rutin sanitasi kandang } \\
\text { dan vaksinasi serta pengkontrolan ternak produktif. }\end{array}$ \\
\hline & Ternak Ternak & $\begin{array}{l}\text { 2. Bekerjasama dengan Puskeswan (Pusat Kesehatan } \\
\text { Hewan) setempat. }\end{array}$ \\
\hline & $\begin{array}{l}\text { 3. Pemotongan } \\
\text { Sapi Betina }\end{array}$ & $\begin{array}{l}\text { Memperketat pada pengawasan dan memberi saksi terhadap } \\
\text { pelaku. }\end{array}$ \\
\hline & $\begin{array}{l}\text { 4. Keamanan } \\
\text { Lingkungan }\end{array}$ & $\begin{array}{l}\text { Melibatkan aparat penegak hukum dan tokoh adat yang bisa } \\
\text { meminimalisir terjadinya kejahatan. }\end{array}$ \\
\hline & $\begin{array}{l}\text { 5. Pengawasan } \\
\text { Dinas }\end{array}$ & $\begin{array}{l}\text { 1. Perlu dan harus ditingkatkan lagi pengawasan oleh dinas } \\
\text { peternakan dalam menjalankan program ini. }\end{array}$ \\
\hline & Kurang & $\begin{array}{l}\text { 2. Perlu tinjau ke lapangan langsung hasil program integrasi } \\
\text { ini. }\end{array}$ \\
\hline & & 3. Memberikan sanksi bagi pelanggar aturan. \\
\hline & & $\begin{array}{l}\text { 4. Memberikan reward bagi peternak yang disiplin dan } \\
\text { sukses dalam program integrasi ini. }\end{array}$ \\
\hline & & $\begin{array}{l}\text { 5. Memberikan jangka waktu dalam menulis hasil dari } \\
\text { laporan hasil perkembangan. }\end{array}$ \\
\hline
\end{tabular}

Sumber: Hasil penelitian, 2019.

\section{SIMPULAN DAN SARAN}

\section{Simpulan}

Simpulan dari penelitian ini adalah bahwa pelaksanaan program sistem integrasi sapi dengan perkebunan kelapa sawit belum sepenuhnya optimal. Limbah ternak sapi sudah dimanfaatkan sebagai pupuk di perkebunan sawit, namun limbah sawit belum dimanfaatkan sebagai pakan ternak karena pakan yang tersedia masih mencukupi untuk ternak yang dipelihara oleh peternak sapi. Kendala yang dihadapi dalam pelaksanaan program integrasi ini adalah berupa pengetahuan dan juga keterampilan petani-ternak yang masih rendah, serta pengawasan dari pemerintah yang masih kurang, sehingga harus ada alternarif solusi dan kebijakan tepat untuk bisa mengembangkan usaha sistem integrasi ini.

\section{Saran}

Untuk bisa mengoptimalkan pelaksanaan program sistem integrasi di masa mendatang, disarankan untuk meningkatkan pengetahuan peternak tentang integrasi tanaman dan ternak, melalui penyuluhan dan pelatihan, terutama dibidang manajemen dan teknologi pengolahan limbah tanaman untuk pakan, serta pengolahan limbah ternak untuk dijadikan pupuk tanaman.

\section{DAFTAR PUSTAKA}

Aksi Agraris Kanisius (AAK). 2011. Petunjuk Beternak Sapi Potong dan Kerja. Kanisius. Yogyakarta.

Arfa'i. 2009. Potensi dan strategi pengembangan usaha sapi potong di Kabupaten Lima Puluh Kota Sumatera Barat. Disertasi. Program Pasca Sarjana Institut Pertanian Bogor. Bogor.

Aritonang, D. 1986. Perkebunan kelapa sawit. Sumber pakan ternak di Indonesia. Jurnal Badan Litbang Pertanian 4: 93.

Badan Pusat Statistik (BPS) Pasaman Barat. 2018. Pasaman Barat dalam angka 2018. Badan Pusat Statistik Provinsi Sumatera Barat.

Badan Pusat Statistik. 2010. Sensus penduduk tahun 2010. http://sp2010.bps.go.id/. Diakses pada 20 September 2017.

Badan Standar Nasional Indonesia (SNI). 2015. Standar Pemilihan Bibit Sapi Bali. SNI:7651.4.2015.http://sisni.bsn.go.id/ind ex.php?/sni_main/sni/detail_sni/22845. Diakses pada 21 September 2018.

Departemen Pertanian. 2010. Kebijakan Pengembangan Sapi Potong di Indonesia. Prosiding Workshop Nasional Dinamika dan Keragaan Sistem Integrasi Ternak- 
Tanaman: Padi, Sawit, Kakao. (In Press). Pusat Penelitian dan Pengembangan Peternakan. Bogor.

Direktorat Jendral Bina Produksi Peternakan. 2012. Pedoman Umum Integrasi Tanaman dan Ternak. Jakarta.

Direktorat Jenderal Peternakan dan Kesehatan Hewan. 2017. Populasi Sapi Potong dan Konsumsi Daging Nasional di Indonesia. Dirjen Peternakan dan Keswan. Departemen Pertanian. Jakarta.

Direktorat Pakan Ternak. 2011. Pedoman Umum Pengembangan Integrasi Ternak. Direktorat Jendral Peternakan dan Kesehatan Hewan, Kementrian Pertanian RI. Jakarta.

Direktorat Pembibitan Ternak. 2012. Pedoman Pelaksanaan Uji Performan Sapi Potong. Direktorat Jenderal Peternakan dan Kesehatan Hewan, Kementerian Pertanian. Jakarta.

Diwyanto, K. 2008. Pemanfaatan Sumber Daya Lokal dan Inovasi Teknologi dalam Mendukung Pengembangan Sapi Potong di Indonesia. Pengembangan Inovasi Pertanian 1 (3):173-188.

Hafez, E.S.E., and B. Hafez. 2013. Reproduction in Farm Animal. $7^{\text {th }}$ ed. Jhon Willey \& sons.

Mathius, I. W., A. P. Sinurat, D. P. Tresnawati dan B. P. Manurung. 2007. Suatu kajian pakan siap saji berbasis produk samping industri kelapa sawit untuk sapi bunting. http://Puslitpetra.ac.id/Puslit/Journals (online). Diakses pada 27 September 2018.

Peraturan Menteri Pertanian (Permentan). 2015. Peraturan Menteri Pertanian
No.46/Permentan/PK.210/8/2015 tentang Pedoman Pembibitan Sapi Potong Yang Baik. Menteri Pertanian RI. Jakarta.

Pasaribu, F. 2007. Hubungan karakteristik pegawai dengan produktivitas kerja. $J$. Ichsan Gorontalo 2(1): 627-637.

Rosita. 2004. Pemanfaatan pelepah dan solid kelapa sawit sebagai pakan sapi di lahan kering Kalimantan Selatan. Balai Pengkajian Teknologi Pertanian. Kalimantan Selatan.

Saragih. B. 2000. Agribisnis Berbasis Peternakan. Ed ke-2. USESE Foundation dan Pusat Pembangunan. Institut Pertanian Bogor. Bogor.

Simamora, B. 2008. Panduan Riset Perilaku Konsumen. PT. Gramedia. Jakarta.

Soeharsono, R. A. Saptati dan K. Diwyanto. 2010. Kinerja Reproduksi Sapi Potong Lokal dan Sapi Persilangan Hasil Inseminasi Buatan di Daerah Istimewa Yogjakarta. Prosiding Seminar Nasional Teknologi Peternakan dan Veteriner. Pusat Penelitian dan Pengembangan Peternakan. Bogor.

Soekartawi. 2002. Prinsip Dasar Manajemen Pemasaran Hasil - Hasil Pertanian (Teori dan Aplikasi). Raja Grafindo Persada. Jakarta.

Umar, S. 2009. Potensi Perkebunan Kelapa Sawit Sebagai Pusat Pengembangan Sapi Potong dalam Merevitalisasi dan Mengakselerasi Pembangunan Peternakan Berkelanjutan. Pidato Pengukuhan Jabatan Guru Besar Tetap dalam Bidang Ilmu Reproduksi Ternak pada Fakultas Pertanian Universitas Sumatera Utara. Medan. 